\title{
Estimation of wettability from well log and laboratory measurements for clastic rocks
}

\author{
Estymacja zwilżalności przy wykorzystaniu danych geofizyki wiertniczej oraz pomiarów \\ laboratoryjnych w skałach klastycznych
}

\author{
Anita Lis-Śledziona \\ Oil and Gas Institute - National Research Institute
}

\begin{abstract}
This paper presents a unique method to calculate a wettability index based on well log data and laboratory measurements performed on cores. The subject of the research is middle Cambrian sandstone located in the offshore part of the Baltic Basin. Cambrian oil production horizons have a form of structural traps associated with faults. In the research, the measured wettability values using the Amott-Harvey test and available well log data were used. In the first stage, the dependence between different petrophysical parameters and measured wettability index values was analysed. The average pore sizes and capillary water content were calculated. It was noted that capillary water saturation and pore sizes that build the pore space have an impact on wettability. Analyses of 10 wells enabled the development of an equation to calculate the saturation exponent $N$. Then, the results of the $N$ parameter were compared against the values from the Amott-Harvey test and a continuous curve of wettability on the Amott-Harvey scale was calculated. Other objectives of this study included assessments of the effect of wettability on formation resistivity, water saturation, and relative permeability to oil and water in the sandstone reservoir. The last part of the performed work included rock-typing and determination of the variability of wettability, water saturation, and relative permeability for each unit. Rock-typing was performed using Principal Component Analysis and the K-mean clustering method. As an input, calculated and core-calibrated permeability and porosity values were used. The reservoir was divided into three classes. The final stage of work indicated the dominant wettability system in the reservoir.
\end{abstract}

Key words: wettability, water and oil relative permeability, water saturation, Amott-Harvey test, hydraulic flow units.

STRESZCZENIE: Artykuł prezentuje nowatorską metodę obliczania zwilżalności przy wykorzystaniu danych geofizyki wiertniczej oraz pomiarów laboratoryjnych wykonanych na rdzeniach. Obszar badań to piaskowce kambru środkowego zlokalizowane w morskiej części basenu bałtyckiego. Akumulacje ropy w tym złożu zlokalizowane są w pułapkach strukturalnych i mają związek z występowaniem uskoków. W pracy jako dane wejściowe wykorzystano wyniki zwilżalności oznaczone laboratoryjnie na próbkach przy wykorzystaniu testu Amotta-Harvey'a oraz dostępne pomiary geofizyki wiertniczej. Celem pracy było także zbadanie wpływu zwilżalności na oporność skały, wartości współczynnika nasycenia wodą oraz zbadanie zależności pomiędzy zwilżalnością a rozmiarem porów budujących przestrzeń porową. Pierwszy etap pracy obejmował obliczenie zawartości wody kapilarnej średnich wielkości porów. Zauważono, że wyliczone parametry zależą od pomierzonej zwilżalności - to spostrzeżenie pozwoliło na zdefiniowanie wzoru do wyznaczania parametru zwilżalności $N$. Następnie uzyskaną ciągłą krzywą obrazującą zmiany zwilżalności wzdłuż całego analizowanego interwału zbiornikowego korelowano z wartościami z testu Amotta-Harvey'a, co pozwoliło na wyliczenie zwilżalności ośrodka w skali Amotta-Harvey'a $(-1 ;-1)$. W kolejnym etapie analizowano wpływ zwilżalności na rzeczywistą oporność formacji, współczynnik nasycenia wodą oraz względną przepuszczalność dla wody i ropy. Ostatnia część wykonanych prac objęła podział piaskowców kambru środkowego na jednostki jednorodne hydraulicznie i określenie zmienności zwilżalności, współczynnika nasycenia wodą i względnej przepuszczalności w każdej z wydzielonych klas. Wydzielenie jednostek jednorodnych hydraulicznie zostało przeprowadzone na podstawie analizy składowych głównych oraz grupowania metodą k-średnich. Ostatnim etapem było określenie dominującego w złożu systemu zwilżalności.

Słowa kluczowe: zwilżalność, przepuszczalność względna dla wody i ropy, współczynnik nasycenia wodą, test Amotta-Harvey’a, jednostki jednorodne hydraulicznie.

Corresponding author: A. Lis-Śledziona, e-mail: lis@inig.pl

Article contributed to the Editor: 29.01.2020. Approved for publication: 23.06.2020 


\section{Introduction}

Rock wettability affecting relative permeability and capillary pressure is one of the factors that impacts the flow mechanism of a reservoir. Knowledge of reservoir wettability is crucial to determine effective production and choose suitable recovery methods for the reservoir (Natari, 2015). Moreover, wettability affects fluid movements through the pore space. For efficient oil recovery, it is important to understand the relationship between the distribution of fluids in the pore space and wettability (Kułynycz, 2017). Numerous methodologies for measuring and studying the wettability of reservoir rocks can be found in the literature (Amott, 1959; Anderson W.G., 1986a 1986b, 1987a, 1987b; Anderson G.A., 2006; Donaldson and Alam, 2008; Al-Sayari, 2009).Wettability is the property of rock that determines "the tendency of one fluid of a fluid pair to coat the surface of a solid spontaneously" (Jerauld and Rathmell, 1997) or, according to Anderson, "it is a tendency of one fluid to spread on or adhere to a solid surface in the presence of other immiscible fluids". Wettability can be also defined by the contact angle of the fluid with the solid phase. The rock surface can be oil-wet or water-wet depending on the preference of the fluid to coat the rock surface. Knowledge about rock wettability is necessary to understand the flow of reservoir fluids, from oil-migration processes from the source rock to the mechanism of fluid flow in reservoir rock. It also allows intensification of recovery processes. If two immiscible phases contact the solid surface, one of them is usually attracted to the solid with greater strength than the other. The phase that is attracted more strongly is called the wettable phase. The wettability of a rock is often determined by measuring the angle between the straight tangent to the liquid at the point of contact with the rock and its surface. The contact angle depends on the surface tension of the contacting liquids, surface energy, and solid phase properties. The type of rock and the chemical composition of the liquid have a significant impact on the value of the contact angle. Wettability is a property affecting capillary pressure, electrical properties, relative permeability, water production, and enhanced oil recovery (Desbrandes, 1989). Because of the effects on the distribution of reservoir fluids, wettability becomes a crucial parameter in understanding rock behaviour and control of fluid movements through pore spaces. So far, there is no direct, in situ method to measure wettability, and therefore it is necessary to estimate this parameter from laboratory measurements (Amott-Harvey test, contact angle). The relation between measured wettability pore sizes, irreducible water saturation, and permeability were studied. As a result, a new method to calculate wettability using well log data is proposed. The results were compared with measured values obtained during the Amott-Harvey test.

\section{Wettability classification}

Two types of wettability classification are presented: homogenous and heterogeneous. The homogenous classification includes three types of rocks:

- water-wet is when water occupies small pores and the surface of the rock while oil occupies the centre of large pores. The oil is trapped as disconnected blobs in the centre of big pores (Majkrzak, 2016);

- neutral/intermediate wet is when there is no preference of the wetting system in the rock;

- an oil-wet system is when oil occupies small pores of the rock while water occupies larger pores. The oil cannot be trapped and residual oil saturation is close to zero, as the oil will always find a path to escape.

The other classification related to heterogeneous wetting divides the rock into two types:

- fractional wettability, a condition in which the rock has a portion that is strongly oil wet and a portion that is strongly water-wet. It happens with crude oil/heavy oil immersion in certain areas (Natari, 2015);

- mixed wettability rock has a portion in which the small pores are water-wet and large pores are oil-wet. As initial oil saturation increases, the rock becomes less water-wet, which decreases the residual oil saturation. Oil can only be trapped at very high water saturation when some of the escape paths are completely disconnected (Masalmeh, 2002).

\section{Geological settings}

The Polish part of the Baltic region is located between two geological units: the East European Craton (EEC) and the Palaeozoic platform of Central and Western Europe (Karnkowski et al., 2010). The subject of the performed research is Middle Cambrian sandstone located in the offshore part of the Baltic Sea. Cambrian oil production horizons have a form of structural trap associated with faults along which the migration of hydrocarbons has occurred. The reservoir properties decrease with depth. Although petrophysical flow parameters such as porosity and permeability of the sandstone might be very different from one well to another, it was stated that almost the whole area of the Polish part of the Peribaltic Syneclise has exploration prospects (Karnkowski et al., 2010). The petrophysical parameters are characterised by high variability, which was observed during well log interpretation. The various shale volume, effective porosity, and permeability affect the accumulation properties of the analysed reservoir. Diagenesis processes, such as compaction, cementation, dissolution, and burial depth, were the main cause of porosity and 
permeability reduction in the Middle Cambrian sandstone. The most prospective for hydrocarbon accumulation is the sandstone containing thin interbeds of sandstone-mudstone heteroliths (Sikorska and Jaworowski, 2007). The variability in pore-size distribution affect pore-throat connectivity, which will have an impact on the volume of irreducible water saturation and rock wettability.

\section{The input data}

The data used in this research come from 10 wells located offshore. The basic well log data available in each well were: gamma ray (GR), neutron porosity (NPHI), bulk density (RHOB), compressional slowness (DT), resistivity measurements from deep and shallow laterologs, as well as laboratory measurements of porosity, pore sizes, permeability, and wettability. The porosity and pore sizes were measured using the Mercury Injection Capillary Pressure method while wettability was measured with an Amott-Harvey test. The measurements were conducted by INiG - PIB for an oil and gas company, which gave permission to use the data. The method to measure the average wettability of a core is based on both spontaneous imbibition and forced displacement of fluids into a core. The commonly used method for the qualitative wettability measure-

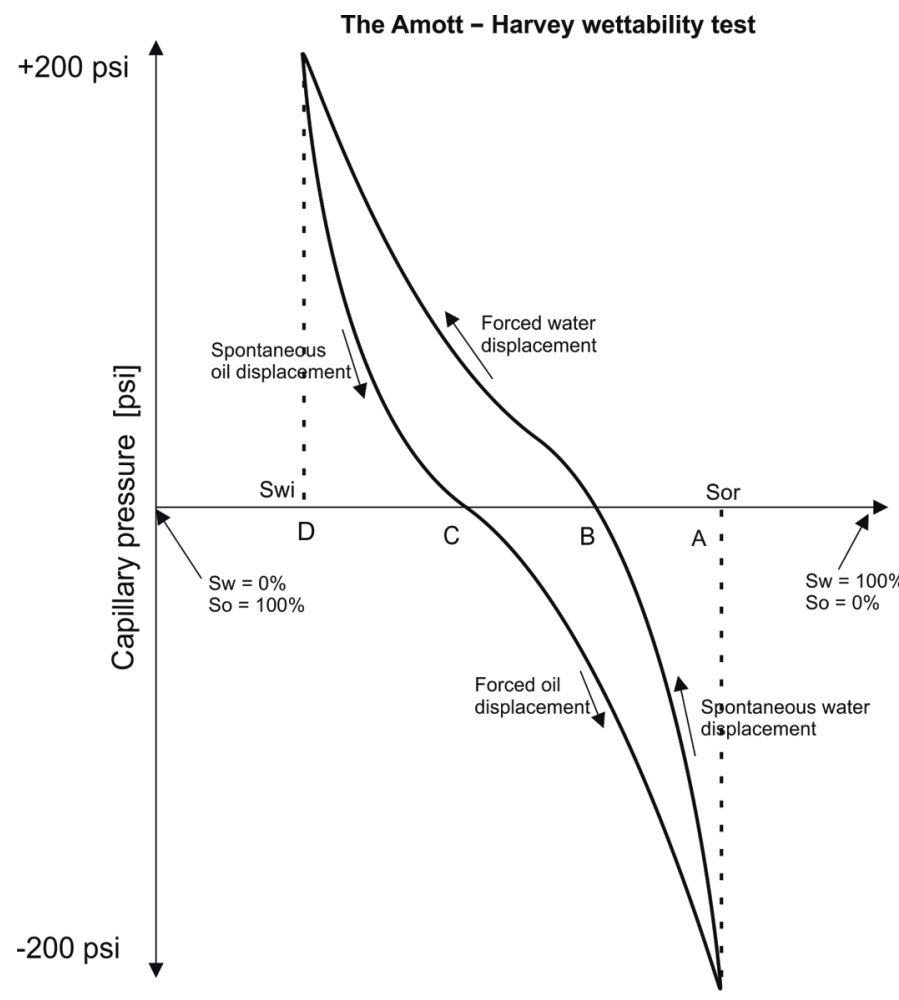

Fig. 1. An Amott-Harvey wettability test diagram (according to Tiab and Donaldson, 2015)

Rys. 1. Schemat testu zwilżalności Amotta-Harvey'a (wykonany na podstawie Tiab i Donaldson, 2015) ment is the imbibition method. A summary of the methods for wettability measurements was given by Anderson (Anderson, 1986a). The performed Amott-Harvey test involved four steps, presented in Figure 1.

The test starts with the residual oil saturation of the sample. Residual oil saturation is obtained by forcibly displacing oil with water.

1. The core is immersed in oil for 24 hours, after which the volume of spontaneously displaced water is measured (test in reservoir temperature) $(A B)$.

2. Water is forced out of the sample until it reaches residual water saturation (Swi). The volume of water forced out is measured $(B D)$.

3. The core is immersed in brine for 24 hours and the volume of spontaneously displaced oil is measured $(D C)$.

4. The oil remaining in the core is forced out by water up to the point of residual oil saturation, and the volume of displaced oil is measured $(C A)$.

Only oil-wet samples spontaneously imbibe oil, while waterwet samples only spontaneously imbibe water. At the end of the experiment, the Amott-Harvey wettability index $(A W I)$ is calculated according to the equation (1).

$A W I=\frac{\text { SpontaneousWaterDisplaced }}{\text { TotalDisplacedWater }}-\frac{\text { SpontaneousOilDisplaced }}{\text { TotalDisplacedOil }}$

The Amott-Harvey method is probably the most accurate and reliable for use with neutral wettability rocks. In the analysed wells, several measurements of wettability were usually performed. For water-wet samples, the $A W I$ ranged from -1 to 0 , neutral wet samples had an $A W I$ between 0 and 0.25 , while oil-wet rocks had the highest values of $A W I$, from 0.25 to 1 . Wettability affects permeability, electrical properties, nuclear magnetic resonance relaxation time, and saturation profiles in the reservoir. Also, water flooding and aquifer encroachment into the reservoir are affected by the wetting stage.

\section{Wettability calculation method based on well log data}

Wettability varies from point to point depending on surface roughness, immobile adsorbed liquid layers, and the adsorptive properties of the minerals (Falode and Manuel, 2014). As prework, the author performed well-log-data interpretation for each well and calculated reservoir properties as shale volume, effective and total porosity, permeability, water saturation, and irreducible (capillary) water saturation according to Zawisza's formula (Zawisza and Nowak, 2012). Also average pore sizes were calculated based on the correlation between measured permeability and pore sizes (Fig. 2). Well-connected intergranular 
pores have large pore throats, which contribute to permeability increases (Kashif et al., 2019). Also electrical resistivity is an important petrophysical property. Wettability and the saturation history of the core have an impact on the fluid distribution within the pore space and affect the resistivity of the electrical pathways through the porous system. Tiab and Donaldson (2015) prove that resistivity is proportional to the current flow and the length of the electrically conductive paths. Generally, rock is treated as an insulator but if clay minerals and metals are present in the rock, they will lower the resistivity. Hydrocarbons are also insulators. Wettability variation will affect the saturation exponent $N$ and formation resistivity factor $F$, both essential during hydrocarbon saturation determination. A number of laboratory test were performed that proved the value of $N$ depends on wettability conditions (Kułynycz, 2017).

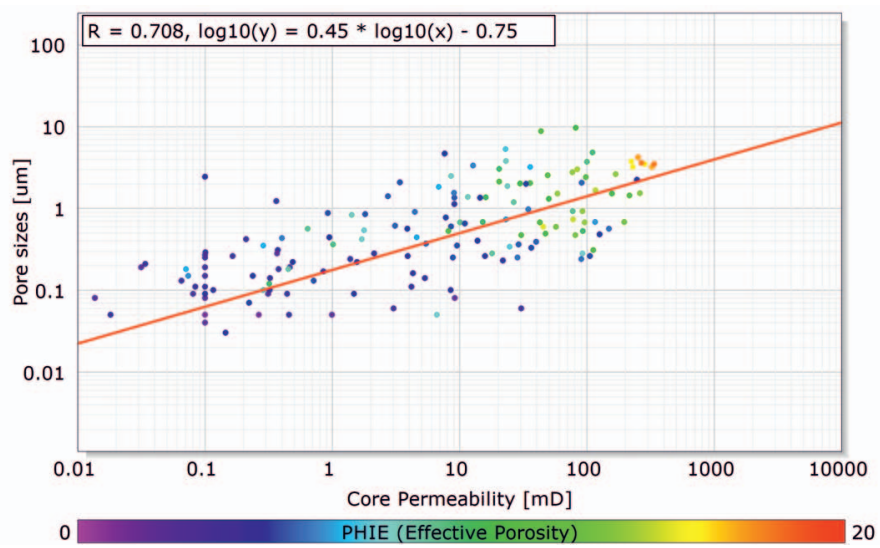

Fig. 2. A multi-well cross plot between core measured permeability and pore sizes. The cross plot shows data from wells A-1, A-2, A-4, A-6, and A-7. The colour scale presents the values of the measured porosity

Rys. 2. Wykres krzyżowy pomiędzy pomierzonymi wartościami przepuszczalności i rozmiarami porów. Wykres przedstawia dane z otworów: A-1, A-2, A-4, A-6 i A-7. Skalą barw oznaczono pomierzone laboratoryjnie wartości porowatości

The aim of the study was to find a method to estimate wettability using well log data and the results of laboratory measurements. A number of correlations between well log data and measured wettability were determined. It was noticed that measured wettability $(A W I)$ depends on calculated irreducible water saturation and pore sizes. In the literature, roughness is also pointed to as a parameter that can influence wettability values (Park et al., 2017). It was noted that generally water-wet samples have higher values of capillary water saturation (Swi), while the pore sizes are higher for the oil-wet samples (Fig. 3). Capillary water saturation (Swi) was calculated using Zawisza's formula calibrated for the offshore part of the Baltic Basin. Wettability also varies with surface roughness, so the wettability of a rock will vary with grain shape, size, and rounding (Crain's Petrophysical Handbook, 2017).

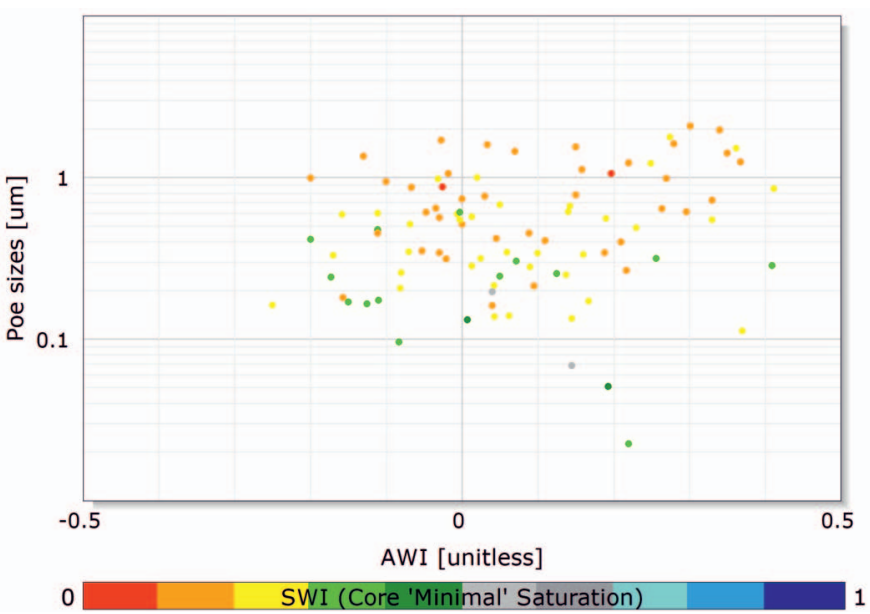

Fig. 3. A multi-well cross plot of a laboratory-measured AmottHarvey index and calculated, core-calibrated pore sizes. The cross plot presents data from all analysed wells: A-1-A-10. The colour scale refers to capillary water saturation calculated from Zawisza's formula

Rys. 3. Wykres krzyżowy pomiędzy wartościami zwilżalności pomierzonymi testem Amotta-Harvey'a a wyliczonymi rozmiarami porów skalibrowanych wartościami pomiarów laboratoryjnych na rdzeniach. Wykres prezentuje dane pochodzące z wszystkich analizowanych otworów (A-1-A-10). Skalą barw oznaczono nasycenie wodą kapilarną obliczoną w oparciu o równanie Zawiszy

In the study the author proposes expressing the saturation exponent $\mathrm{N}$ through the petrophysical parameters that have an impact on rock wettability. As a result, Equation 2 is proposed. It takes into account the three mentioned variables that affect wettability values.

$$
N=S w i{ }^{a} \cdot \frac{P^{b}}{R}
$$

Where $N$ is the unitless saturation exponent index, Swi is capillary water saturation, $P$ stands for pore sizes in micrometres, $a$ and $b$ are calibration constants and were empirically set as $a=0.2$ and $b=2 . R$ is roughness in micrometres.

The values of $N$ can be identified as the saturation exponent. The laboratory measurements of this parameter in sandstone can vary from 1.22 to 4.36 (Zalewska and Cebulski, 2010). The values of calibration constants $a$ and $b$ should be experimentally set, based on the information of the saturation exponent values in the analysed formation. It will be easier to set/calibrate these parameters if there are some measurements of the saturation exponent available for the analysed wells. The values of roughness are generally unknown and difficult to estimate. In this study, the values of $R$ were assumed according to the results of roughness measurements performed on sandstone in Park's article (Park et al., 2017). The values of $R$ range from 0.2 to $0.9 \mathrm{um}$. Three sets of calculations were performed for $R=0.2$ and $R=0.6$ and $R=1$. The results of $N$ were correlated with the measured wettability $A W I$. The relationship between $N$ and $A W I$ describe Equation 3 . 


$$
\begin{gathered}
A W I_{-} \text {cor }=0.197 \cdot \log 10 N+0.23 \\
A W I_{\text {cor }}=0.197 \cdot \log 10\left(\text { Swi }^{a} \cdot \frac{P^{b}}{R}\right)+0.23
\end{gathered}
$$

Figure 4 shows the calculated values of wettability (AWI_cor) calculated for three sets on $N(0.2 ; 0.6$; and 1$)$. The black dots are the measured wettability values during the Amott-Harvey test.

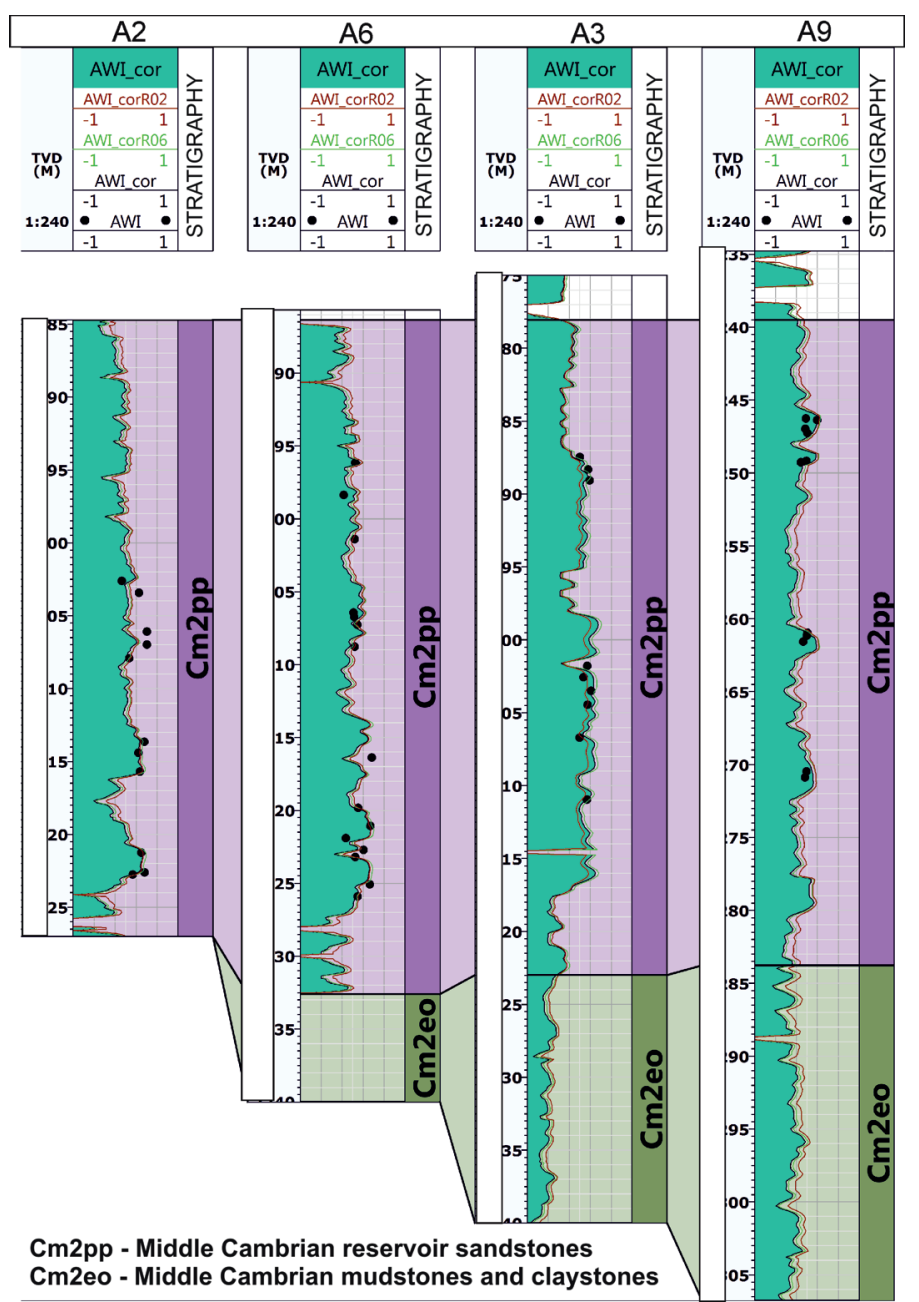

Fig. 4. The values of calculated wettability $A W I$ cor $(R=1)$, AWI_corR06 $(R=0.6)$, and AWI_corR02 $(R=0 . \overline{2})$ and AmottHarvey test values of wettability (black dots) in four wells

Rys. 4. Wartości obliczonych parametrów zwilżalności: $A W I$ cor $(R=1), A W I$ corR06 $(R=0,6), A W I \_c o r R 02(R=0,2)$ i pomierzone testem Amotta-Harvey'a wartości zwilżalności (czarne kropki) dla czterech interpretowanych odwiertów

The correlation between parameter $N$ (for $R=0.6$ ) and the results of the Amott-Harvey wettability test is presented in Figure 5. The determination of dependence between the calculated saturation exponent $(N)$ and measured values of the Amott-Harvey index were crucial as it enables a calculation of the continuous curve of wettability in the reservoir. The proposed Equation 2 has the fundamental meaning in the wettability index calculation, while Equation 3 allows to recal- culate the wettability values to the Amott-Harvey scale $(-1 ; 1)$. The coefficients $a$ and $b$ were experimentally set for this reservoir based on the analysis from 10 wells. The low correlation coefficient $\left(R^{2}=0.328\right)$ could be related to a few things: depth mismatch between laboratory measurements and well logs, a scale problem, or low variability of $A W I$ cor (values mainly ranges from -0.2 to 0.3 ), which represent basically a neutral-wet system, caused difficulties in obtaining a strong correlation. However the calculated values of AWI_cor show quite a good match to the measured $A W I$ values (Fig. 4). This method needs to be developed and tested in other reservoirs.

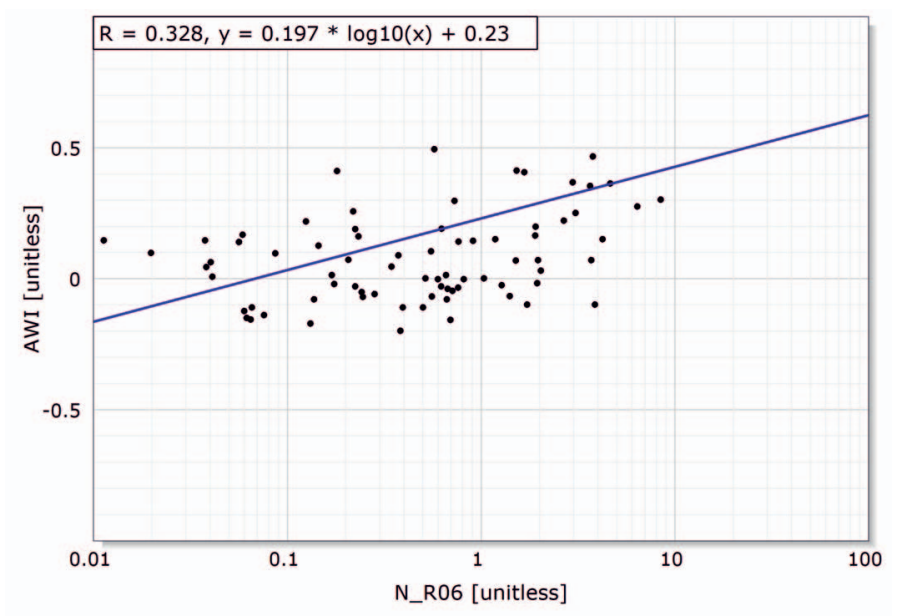

Fig. 5. The correlation between calculated wettability index $N \_R 06$ and the measured Amott-Harvey index (AWI)

Rys. 5. Korelacja między obliczonym parametrem zwilżalności $N \_R 06$, a zwilżalnością $(A W I)$ pomierzoną testem Amotta-Harvey’a

\section{The dependence of calculated wettability (AWI_cor) from resistivity and water saturation}

The next step after the calculation of wettability (AWI_cor) in the 10 wells was to check how AWI_cor depends on the water saturation coefficient and measured deep resistivity. Calculated AWI_cor values show strong dependence of water saturation and formation resistivity (Figs. 6 and 7). Figure 6 clearly shows that, depending on the water saturation of the rock, there is a different relation between formation resistivity and wettability of the rock. The correlation was made only in the Cambrian sandstone intervals. The intervals that are fully water-saturated are generally strongly water-wet, with wettability values of $-1 ;-0$ and formation resistivity lower than $100 \mathrm{ohm} . \mathrm{m}$. The intervals with water saturation between 0.8 and 0.2 and formation resistivity below $400 \mathrm{ohm}$.m show a mixed and neutral wettability system where $A W I$ cor ranges from 0 to 0.25 . Oil-saturated intervals with $S W 0.1 ;-0.2$ and resistivity from $20-1000$ ohm.m represent oil-wet rocks. However, the values of $A W I$ do not exceed 0.35 , which suggests that the 
reservoir is mainly of water-wet and mixed wettability type. Table 1 contains equations for five different water saturation ranges presented in Figure 6. The correlation in log-log scale between resistivity index and water saturation (Fig. 7A) indicates a linear relation between $R I S W$ for oil-saturated intervals where $S W$ is lower than 0.2 , but when the amount of water

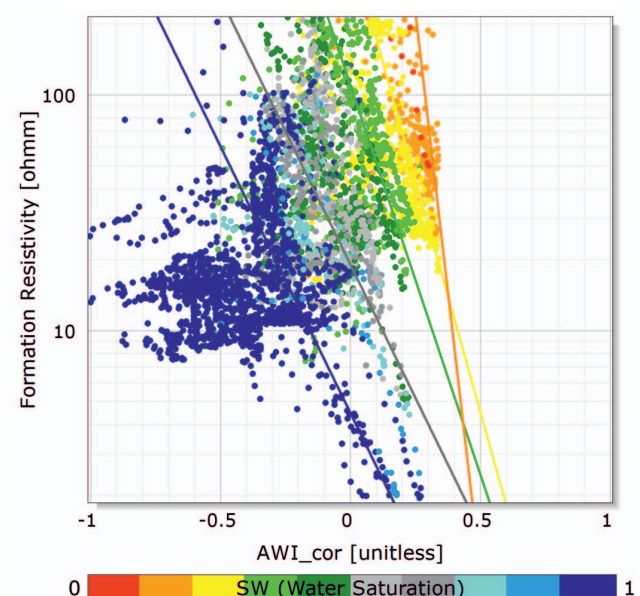

Fig. 6. A multi-well cross plot between calculated wettability and formation resistivity; colour scale refers to the water saturation coefficient. Five correlation lines were drawn for different $S W$ ranges: $S W(0-0.2)$, orange line; $S W(0.2-0.3)$, yellow line; $S W(0.3-0.5)$, green line; $S W(0.5-0.9)$, grey line, and $S W(0.9-1)$, blue line

Rys. 6. Wykres krzyżowy pomiędzy obliczonymi wartościami zwilżalności i opornością skały. Wykres prezentuje dane dla kilku interpretowanych odwiertów. Skalą barw oznaczono wartości współczynnika nasycenia wodą. Poprowadzono 5 linii korelacyjnych dla różnych zakresów zmienności współczynnika nasycenia wodą: $S W(0-0,2)$, pomarańczowa linia; $S W(0,2-0,3)$, żółta linia; SW $(0,3-0,5)$, zielona linia; $S W(0,5-0,9)$, szara linia i $S W(0,9-1)$, niebieska linia

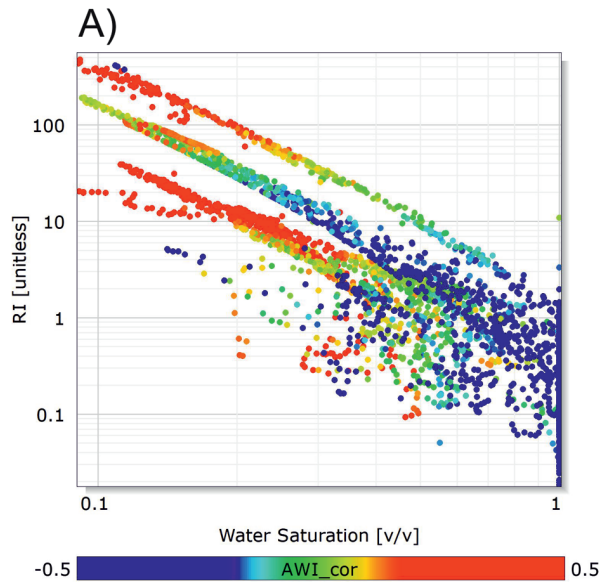

B)

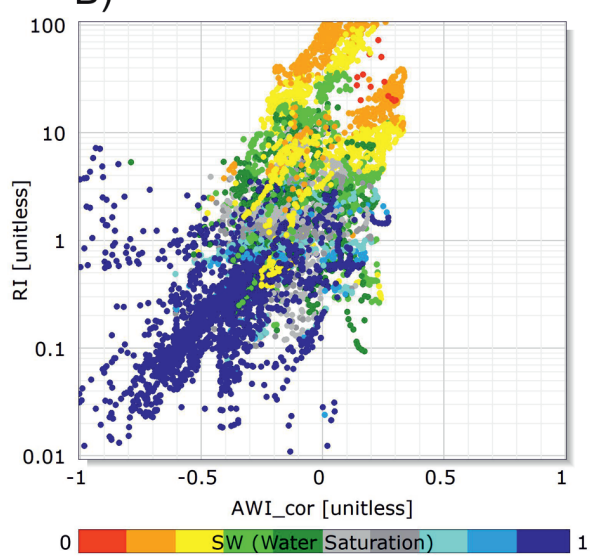

Fig. 7. The log-log dependence between calculated resistivity index $(R I)$ and water saturation; colour scale refers to calculated wettability values $(A)$. The dependence of calculated resistivity index $(R I)$ from calculated wettability ( $\left.A W I \_c o r\right)$; colour scale refers to the water saturation coefficient $(B)$

Rys. 7. Zależność, w skali logarytmicznej, pomiędzy obliczonym indeksem oporności $(R I)$ a współczynnikiem nasycenia wodą. Skalą barw oznaczono obliczone wartości zwilżalności $(A)$. Zależność indeksu oporności $(R I)$ od obliczonej zwilżalności ( $A W I$ cor). Skalą barw oznaczono wartości współczynnika nasycenia wodą $(B)$ increases until there is enough water in the system to create conductive paths, the water paths are connected and the $R I$ curve bends downwards (Montaron, 2007). The resistivity index calculated for the assumed formation water resistivity, hence the dissection of curves for each well in Figure $7 \mathrm{a}$, reveal the curves from different wells are separated, while in Figure 7b, the curves from different wells are definitely grouped. The significant influence of formation water resistivity on the values of $R I$ and $S W$ caused rocks of similar wettability to have different values on the resistivity index, which means that it is not recommended to use $R I$ as an input to perform rock-typing.

Table 1. The equations that represent the dependence between formation resistivity and wettability for five different water saturation ranges defined in Figure 6

Tabela 1. Równania reprezentujące zależność między opornością właściwą ośrodka a zwilżalnością dla pięciu różnych zakresów współczynnika nasycenia wodą wyznaczonych na rysunku 6

\begin{tabular}{|c|c|c|}
\hline SW range & Equations & $\boldsymbol{R}$ \\
\hline \hline $1-0.9$ & $\log 10(\mathrm{RT})=-2.26 \cdot A W I \_c o r+0.65$ & -0.519 \\
\hline $0.9-0.5$ & $\log 10(\mathrm{RT})=-2.26 \cdot A W I \_c o r+1.28$ & -0.841 \\
\hline $0.5-0.3$ & $\log 10(\mathrm{RT})=-3.3 \cdot A W I \_c o r+2.04$ & -0.912 \\
\hline $0.3-0.2$ & $\log 10(\mathrm{RT})=-3.95 \cdot A W I \_c o r+2.63$ & -0.973 \\
\hline $0.2-0$ & $\log 10(\mathrm{RT})=-9.48 \cdot A W I$ cor +4.72 & -0.566 \\
\hline
\end{tabular}

\section{Wettability effects on relative permeability}

The average flow behaviour of immiscible fluids can be described by the relative permeability curves. They also can be used in large-scale flow predictions for applications in improved oil recovery, carbon dioxide storage, and contaminant transport. Raza et al. (1968), Anderson (1987b) and Morrow (1990) in their papers demonstrate that relative permeability depends on wettability, pore structure, and pore connectivity. Measurements of relative permeability are rather expensive and usually limited to a single sequence on a limited number of samples at one wettability condition. Relative permeability is affected by numerous factors, as follow: pore size distribution, wettability, saturation, and saturation history. For each rock in the reservoir, the pore structure in terms of its shape and size is different. The pore structure would affect the relative permeability because reservoir fluids flow through different interconnections. In cases when 
oil/non-wetting phase enters the pore structure, it will occupy the largest pores, which results in water permeability reduction. The conditions of saturation determine the wetting and non-wetting fluids. Moreover saturation may impact the flow path through the rock. There are two processes in the history of fluids saturation. The drainage process when the oil is migrating to the reservoir and displacing the water and imbibition, when water displaces the oil.

The shapes of the relative permeability curves depend on the wetting qualities of the fluids. When the system becomes more oil-wet, the water relative permeability increases while the oil relative permeability decreases (Kułynycz, 2017). Wettability changes significantly affect the efficiency of waterflooding.

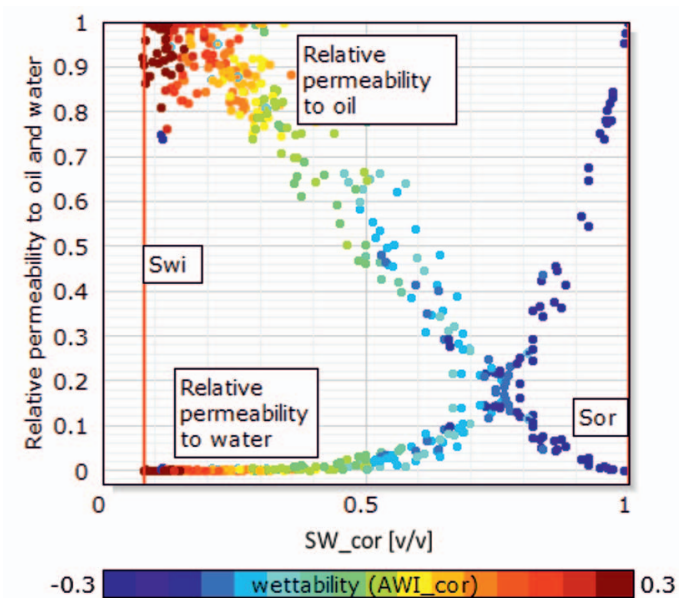

Fig. 8. A cross plot of water saturation and relative permeability to oil and water; colour scale presents the values of wettability, AWI_cor

Rys. 8. Wykres krzyżowy pomiędzy współczynnikiem nasycenia wodą i krzywymi przepuszczalności względnej dla wody i ropy. Skalą barw oznaczono wartości obliczonej zwilżalności, AWI_cor

Figure 8 presents relative permeability curves for oil and water in one of the analysed wells. The saturation crossover is $S W=0.75$ and, according to Craig's rule of thumb, if saturation crossover is more than 0.5 it is an indication of a water-wet system. On the other hand, the residual water saturation $S w i$ is around 0.1 , which according to the above rule indicates that the system is oil-wet (Table 2). In this case, the water relative permeability can rise to high values in all cases as the water fills the centre of the larger regions of the pore space (Gharbi and Blunt, 2012). The values of the $A W I$ parameter suggest that we are dealing with a mixed wettability reservoir in which the rock is partly water-wet and oil-wet. The strong dependence of calculated wettability (AWI_cor) from the relative permeability to oil and water was also noted. Figure 8 presents the relation between water saturation and relative permeability to oil $(K r o)$ and water $(K r w)$. The colour scale presents the values of wettability. Only when relative permeability to oil is high $(0.8-1)$ and $S W$ is low $(0.1-0.2)$ does the reservoir represent an oil-wet wettability system, and AWI is up to 0.3 . If $K r o$ is between 0.2 and 0.8 and $S W$ is in the range of $0.2-0.75$, the system has mixed or neutral wettability with a range of -0.1 to 0.25 , or when $S W$ is higher than 0.75 and $K r o$ is lower than 0.2 , the system is water-wet with an AWI below -0.1 . When relative permeability to water increases, the wettability system changes from oil-wet to water-wet. For water saturation between 0.1 and 0.2 , the system remains oil-wet. When $S W$ is in the range of $0.2-0.75$, the system is neutral. If $S W$ is higher than 0.75 , the rocks are water-wet. The water relative permeability endpoint is low for water-wet samples and increases for mixed-wet or oil-wet samples (Masalmeh, 2002). The dominate wettability system in the analysed sandstone reservoir is mixed type and water-wet. Only intervals with very high hydrocarbon saturation above 0.8 represents oil-wet rocks, (brown dots in Fig. 8).

Table 2. Wettability inference from relative permeability to oil and water, according to Craig's (1971) rules-of-thumb

Tabela 2. Wnioskowanie o systemie zwilżalności na podstawie przebiegu krzywych przepuszczalności względnych dla wody i ropy (Craig 1971)

\begin{tabular}{|l|c|c|}
\hline \multicolumn{1}{|c|}{ Criteria } & Oil-wet & Water-wet \\
\hline \hline Water saturation crossover point & $<50 \%$ & $>50 \%$ \\
\hline Endpoint relative permeability to water Sor & $<50 \%$ & $<30 \%$ \\
\hline Initial water saturation Swi & $<15 \%$ & $>25 \%$ \\
\hline
\end{tabular}

\section{Analysis of wettability changes in different hydraulic units}

The reservoir was subdivided into three classes based on calculated and core-calibrated porosity and permeability curves. The goal of this classification was to subdivide the reservoir into units of different flow properties. The classification was performed using Techlog HRA (Heterogenous Rock Analysis), which is a module in Schlumberger Techlog software 2015.3, used to perform the cluster analysis. In the first step, the module runs a Principal Component Analysis (PCA) then a K-mean clustering algorithm is used to group data into unique classes (Pearson, 1901; Hotelling, 1933). The module was run for different numbers of classes but optimal results were obtained for three units. The box plot below presents the range of porosity and permeability values for each hydraulic unit. Figure 9 shows the variability of flow units with depth in four wells.

Table 4 below presents the variability of wettability, water saturation, formation resistivity, capillary water content and relative permeability to oil and water in each hydraulic unit. 


\section{NAFTA-GAZ}

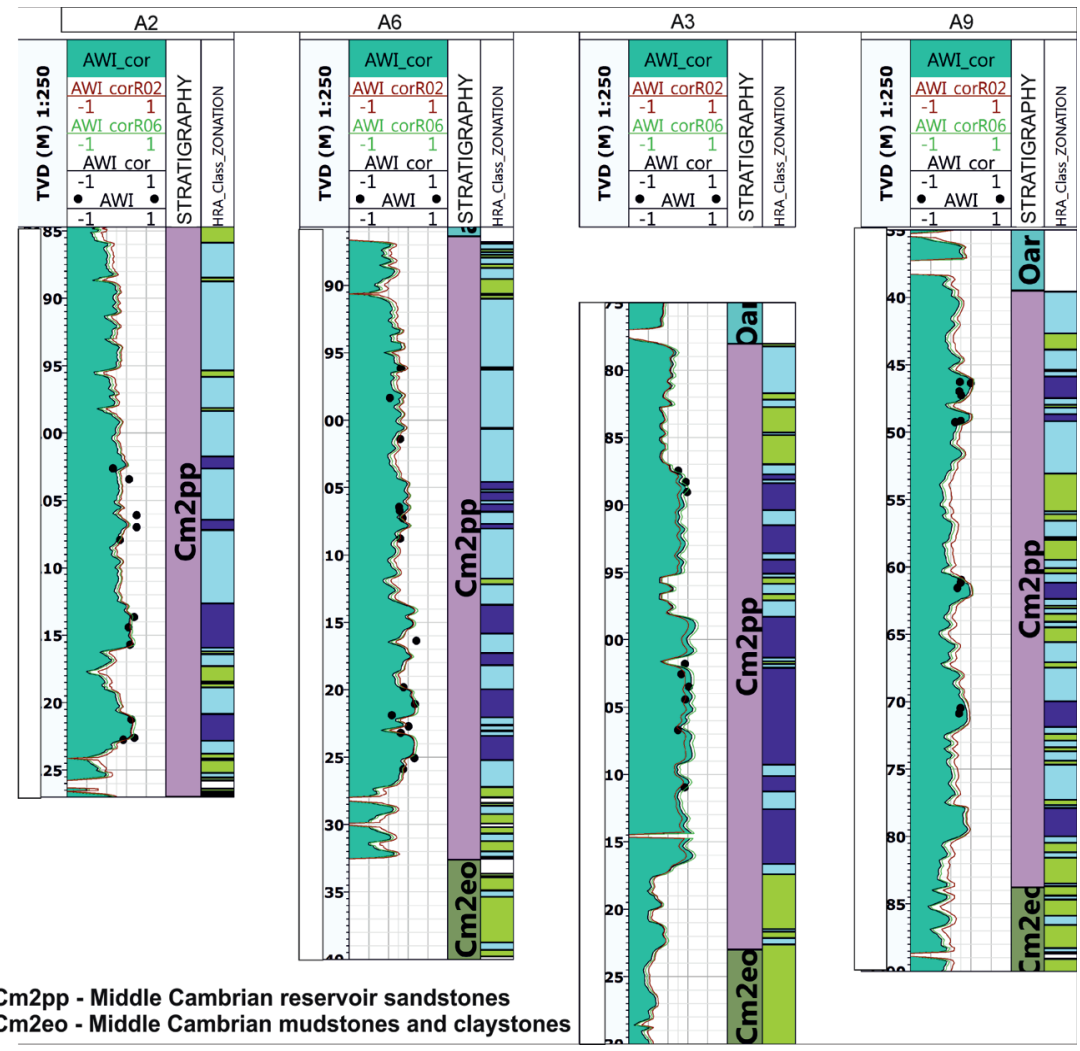

A)

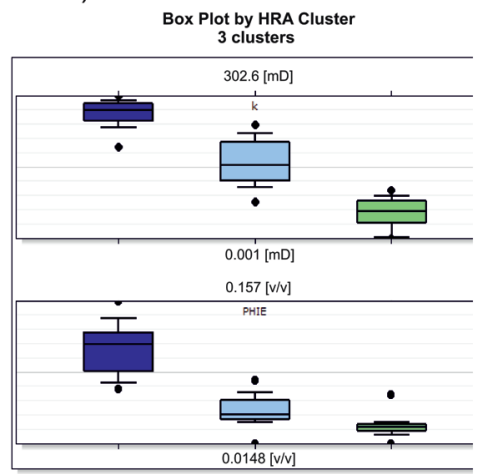

B)

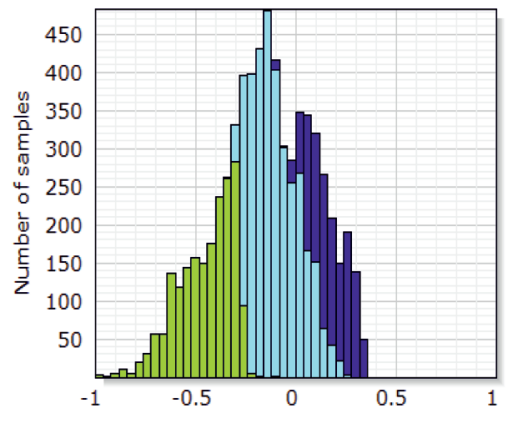

Zonation: HRA Class_ZONATION

$\square$ hydraulic unit $3 \quad \square$ hydraulic unit 2

hydraulic unit 1

Table 3. The variability of the wettability index in each hydraulic unit calculated for all analysed wells

Tabela 3. Zmienność wartości zwilżalności w każdej z jednostek dla wszystkich analizowanych odwiertów

\begin{tabular}{|c|c|c|}
\hline AWI_cor & Min. & Max. \\
\hline \hline HFU 1 & 0.1 & 0.35 \\
\hline$H F U ~ 2$ & -0.3 & 0.23 \\
\hline HFU 3 & -1.0 & -0.23 \\
\hline
\end{tabular}

Fig. 11. A cross plot of water saturation and relative permeability to oil and water; colours refer to different hydraulic units (HFU) identified using the HRA module

Rys. 11. Wykres krzyżowy pomiędzy współczynnikiem nasycenia wodą i przepuszczalnością względną dla wody i ropy. Skalą barw oznaczono wydzielone jednostki hydrauliczne (HFU) zdefiniowane przy wykorzystaniu modułu HRA 
Table 4. The variability of the petrophysical parameters in each subdivided hydraulic unit in well A-3

Tabela 4. Zmienność parametrów petrofizycznych dla trzech wydzielonych jednostek hydraulicznych w odwiercie A-3

\begin{tabular}{|c|c|c|c|c|c|c|c|c|}
\hline Zone name & Variable & Unit range & Minimum & Maximum & $\begin{array}{c}\text { Arithmetic } \\
\text { mean }\end{array}$ & Median & $\begin{array}{l}\text { Standard } \\
\text { Deviation }\end{array}$ & Variance \\
\hline \multirow{6}{*}{$\begin{array}{l}\text { Hydraulic } \\
\text { unit } 1\end{array}$} & AWI_cor & {$[-1 ; 1]$} & 0.00 & 0.35 & 0.17 & 0.18 & 0.16 & 0.03 \\
\hline & $S W \_c o r$ & $\mathrm{v} / \mathrm{v}$ & 0.08 & 0.40 & 0.19 & 0.17 & 0.07 & 0.01 \\
\hline & $R T$ & ohm.m & 96.81 & 719.94 & 358.77 & 325.19 & 139.10 & 19347.75 \\
\hline & Swi & $\mathrm{v} / \mathrm{v}$ & 0.00 & 0.34 & 0.16 & 0.16 & 0.07 & 0.00 \\
\hline & Krw & {$[0 ; 1]$} & 0.00 & 0.00 & 0.00 & 0.00 & 0.00 & 0.00 \\
\hline & Kro & {$[0 ; 1]$} & 0.74 & 1.00 & 0.93 & 0.94 & 0.07 & 0.01 \\
\hline \multirow{6}{*}{$\begin{array}{l}\text { Hydraulic } \\
\text { unit } 2\end{array}$} & AWI_cor & {$[-1 ; 1]$} & -0.28 & 0.04 & -0.10 & -0.11 & 0.10 & 0.01 \\
\hline & $S W \_c o r$ & $\mathrm{v} / \mathrm{v}$ & 0.26 & 1.00 & 0.58 & 0.56 & 0.20 & 0.04 \\
\hline & $R T$ & ohm.m & 18.92 & 373.78 & 133.16 & 113.54 & 81.17 & 6588.02 \\
\hline & Swi & $\mathrm{v} / \mathrm{v}$ & 0.19 & 0.60 & 0.40 & 0.40 & 0.10 & 0.01 \\
\hline & $K r w$ & {$[0 ; 1]$} & 0.00 & 1.00 & 0.13 & 0.03 & 0.21 & 0.05 \\
\hline & Kro & {$[0 ; 1]$} & 0.00 & 1.00 & 0.45 & 0.46 & 0.29 & 0.08 \\
\hline \multirow{6}{*}{$\begin{array}{l}\text { Hydraulic } \\
\text { unit } 3\end{array}$} & AWI_cor & {$[-1 ; 1]$} & -0.93 & -0.26 & -0.55 & -0.58 & 0.16 & 0.02 \\
\hline & $S W \_c o r$ & $\mathrm{v} / \mathrm{v}$ & 0.86 & 1.00 & 1.00 & 1.00 & 0.01 & 0.00 \\
\hline & $R T$ & ohm.m & 13.92 & 98.24 & 23.05 & 17.83 & 12.89 & 166.27 \\
\hline & Swi & $\mathrm{v} / \mathrm{v}$ & 0.47 & 0.94 & 0.76 & 0.79 & 0.10 & 0.01 \\
\hline & $K r w$ & {$[0 ; 1]$} & 0.45 & 1.00 & 0.99 & 1.00 & 0.06 & 0.00 \\
\hline & Kro & {$[0 ; 1]$} & 0.00 & 0.04 & 0.00 & 0.00 & 0.00 & 0.00 \\
\hline
\end{tabular}

\section{Summary and discussion}

The performed work allows the calculation of exponent $N$ based on well log data and laboratory measurements. Based on the input data, the average pore size and capillary water content were calculated. The values of calculated saturation exponent $(N)$ show dependence from the laboratory-measured Amott-Harvey index. The correlation coefficient between $A W I$ cor and $N$ is quite low (0.328), which might be related to a few things: a scale problem, depth match between the laboratory measurements and well log data, or inaccurate estimation of capillary water content or pore sizes. All these factors may have an impact on the obtained values of $N$ and undoubtedly the method needs improvement. However, the correlation between these parameters makes it possible to set up an equation that enables the calculation of a continuous curve of reservoir wettability (AWI_cor) in the Amott-Harvey scale (-1 to 1$)$. The calculated values of AWI_cor show a good match with the measured Amott-Harvey index in 10 analysed wells, as seen in Figure 4. The author will continue improvement of the presented method and will continue to test it with data from other reservoirs that are characterised by higher variability on the Amott-Harvey index. The values of obtained wettability AWI_cor do not exceed 0.4 , which suggests the reservoir is mainly water-wet. Also, the water saturation crossover point is higher than 0.5 , which is characteristic of water-wet reservoirs. On the other hand, the irreducible water saturation values are quite low $(0.1-0.15)$, which is typical for oil-wet reservoirs. This may suggest that the reservoir is not homogenous and can be divided into zones of water-wet and oil-wet. The intervals with higher capillary water content and low average pore size tend to be water-wet, and when the conditions change, the Swi decreases and the pores become larger, then oil can be stored in the centre of larger pores and the reservoir becomes more oil-wet. This classifies this reservoir as mixed-wet.

An assessment of the effect of wettability on formation resistivity, water saturation, and relative permeability to oil and water was also performed. Generally, the reservoir became more water-wet when the formation resistivity and resistivity index decrease. The relation on log-log scale between the water saturation coefficient and resistivity index $(R I)$ is linear only for very low water saturation $(0.1-0.2)$, but when the amount of water increases and there is enough in the system to create conductive paths, the water paths are connected and the $R I$ curve is slightly bending downwards.

As the analysed reservoir is heterogeneous, rock-typing was carried out and the variability of wettability, water saturation coefficient, and relative permeability for each unit was calculated. Hydraulic Unit 1 can be identified as neutral and oil-wet, Hydraulic Unit 2 is related to an interval with neutral wettability, while Hydraulic Unit 3 represents water-wet intervals. 


\section{Acknowledgements}

The author would like to thank LOTOS Petrobaltic S.A. for permission to use the data in this paper.

This paper was written on basis of the statutory work entitled: Badanie relacji pomiędzy parametrem zwilżalności, a opornościa skały $w$ funkcji zmiennego nasycenia woda i różnego rozmiaru porów tworzacych przestrzeń porowa - the work of the Oil and Gas Institute - National Research Institute was commissioned by the Ministry of Science and Higher Education; order number: 0064/ SG/2019, archive number: DK-4100-0054/2019.

\section{References}

Al-Sayari S., 2009. The Influence of Wettability and Carbon Dioxide Injection on Hydrocarbon Recovery. Imperial College of London.

Amott E., 1959. Observations relating to the wettability of porous rock. Trans. AIME, 216: 156-162.

Anderson G.A., 2006. Simulation of Chemical Flood Enhanced Oil Recovery Processes Including the Effects of Reservoir Wettability. The University of Texas at Austin, USA.

Anderson W.G., 1986a. Wettability Literature Survey. Part 2: Wettability Measurement. Journal of Petroleum Technology, 38(12):1246-1262.

Anderson W.G., 1986b. Wettability literature survey. Part 1: Rock/oil/ brine interactions and the effects of core handling on wettability. Journal of Petroleum Technology, 38(11): 1125-1144.

Anderson W.G., 1987a. Wettability literature survey - Part 4: Effects of wettability on capillary pressure. Journal of Petroleum Technology, 39:1283-1300.

Anderson W.G., 1987b. Wettability literature survey part 5: The effects of wettability on relative permeability. JPT J. Pet. Technol., 39(11), 1453-1468. DOI: 10.2118/16323-PA.

Craig F.F., 1971. The Reservoir Engineering Aspects of Waterflooding. SPE Monograph Soc. of Pet. Eng., Richardson, Texas.

Crain's Petrophysical Handbook. < https://spec2000.net/09-wettability. htm> (accessed: 09.09.2019).

Desbrandes R., 1989. In Situ Wettability Determination Improves Formation Evaluation. Petroleum Engineer International, 61(5).

Donaldson E.C., Alam W., 2008. Wettability. Gulf Publishing Company, Texas.

Falode O., Manuel E., 2014. Wettability Effects on Capillary Pressure, Relative Permeability and Irreducible Saturation Using Porous Plate. Journal of Petroleum Engineering, 14: 1-12.

Gharbi O., Blunt M.J., 2012. The impact of wettability and connectivity on relative permeability in carbonates: A pore network modeling analysis. Water Resources Research, 48(12): 12513. DOI: 10.1029/2012WR011877.

Hotelling H., 1933. Analysis of a complex of statistical variables into principal components. Journal of Educational Psychology, 24(6): 417-441. DOI: 10.1037/h0071325.

Jerauld G.R., Rathmell J.J., 1997. Wettability and Relative Permeability of Prudhoe Bay: A Case Study in Mixed-Wet Reservoirs Conference. Society of Petroleum Engineers. DOI: 10.2118/28576-PA.

Karnkowski P.H., Pikulski L., Wolnowski T., 2010. Petroleum geology of the Polish part of the Baltic region - an overview. Geological Quarterly, 54(2): 143-158.
Kashif M., Cao Y., Yuan G., Asif M., Javed K., Mendez J.N., Khan D., Miruo L., 2019. Pore size distribution, their geometry and connectivity in deeply buried Paleogene Es1 sandstone reservoir, Nanpu Sag, East China. Petroleum Science, 16(5): 981-1000. DOI: $10.1007 / \mathrm{s} 12182-019-00375-3$.

Kułynycz V., 2017. The influence of wettability on the petrophysical parameters of reservoir rocks. AGH Drilling, Oil, Gas, 34(3): 775-784. DOI: 10.7494/drill.2017.34.3.775.

Majkrzak M., 2016. Analiza przepływu płynów złożowych w skałach zbiornikowych. Nafta-Gaz, 8: 610-618. DOI: 10.18668/ NG.2016.08.04.

Masalmeh S.K., 2002. The effect of wettability on saturation functions and impact on carbonate reservoirs in the Middle East. Society of Petroleum Engineers. DOI: 10.2118/78515-MS.

Montaron B., 2007. A quantitative model for the effect of wettability on the conductivity of the porous rocks. Society of Petroleum Engineers. DOI: 10.2118/105041-MS.

Morrow N.R., 1990. Wettability and its effect on oil recovery. Journal of Petroleum Technology, 42(12): 1476-1484.

Natari G.N., 2015. Role of Rock Wettability on Relative Permeability and Capillary Pressure Behavior. Universiti Teknologi PETRONAS Final Year Project Academic Subject: Academic Department - Petroleum Geosciences - Petrophysics - Petrophysical data acquisition.

Park J., Baek K., Lee M., Chung Ch., Wang S., 2017. The Use of the Surface Roughness Value to Quantify the Extent of Supercritical $\mathrm{CO}_{2}$ Involved Geochemical Reaction at a $\mathrm{CO}_{2}$ Sequestration Site. Applied Sciences, 7(572). DOI: 10.3390/app7060572.

Pearson K., 1901. LIII On lines and planes of closest fit to systems of points in space. The London, Edinburgh, and Dublin Philosophical Magazine and Journal of Science, 2(11): 559-572. DOI: 10.1080/14786440109462720.

Raza S.H., Treiber L.E., Archer D.L., 1968. Wettability of reservoir rocks and its evaluation. Prod. Mon., 32(4): 2-7.

Sikorska M., Jaworowski K., 2007. Ewolucja porowatości w piaskowcach kambru z polskiej części Morza Bałtyckiego. Biuletyn Państwowego Instytutu Geologicznego, 427: 79-110.

Tiab D., Donaldson E.C., 2015. Petrophysics: Theory and Practice of Measuring Reservoir Rock and Fluid Transport Properties. Fourth Edition, Gulf Professional Publishing is an imprint of Elsevier.

Zalewska J., Cebulski D., 2010. Wyniki laboratoryjnych badań własności elektrycznych skał. Nafta-Gaz, 4: 251-256.

Zawisza L., Nowak J., 2012. Metodyka określania parametrów filtracyjnych skał na podstawie kompleksowej analizy danych geofizyki otworowej. Wydawnictwa Akademii Górniczo-Hutniczej im. St. Staszica w Krakowie.

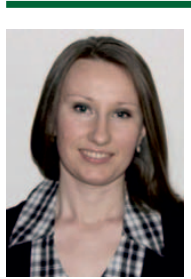

Mgr inż. Anita LIS-ŚLEDZIONA

Asystent w Zakładzie Geologii i Geochemii Instytut Nafty i Gazu - Państwowy Instytut Badawczy ul. Lubicz $25 \mathrm{~A}$

31-503 Kraków

E-mail: lis@inig.pl 